\title{
Prenatal imaging features and postnatal outcomes of isolated fetal duplex renal collecting system: a systematic review and meta-analysis.
}

Short title: Outcome in fetal duplex system

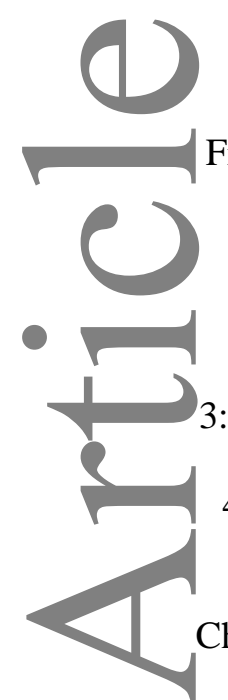

Francesca Bascietto ${ }^{1}$, Asma Khaliil ${ }^{2}$, Giuseppe Rizzo ${ }^{3}$, Alexander Makatsariya ${ }^{4}$, Danilo Buca ${ }^{1}$, Claudia Silvi $^{1}$ Matteo Ucci ${ }^{1}$, Marco Liberati ${ }^{i 1}$, Alessandra Familiari ${ }^{5}$, Francesco D’ Antonio ${ }^{6}$

1: Department of Obstetrics and Gynecology, University of Chieti, Italy

2: Fetal Medicine Unit, Saint George's Hospital, London, United Kingdom

3: Department of Maternal and Fetal Medicine, Ospedale Cristo Re, University of Rome Tor Vergata, Rome, Italy.

4: Department of Obstetrics and Gynecology, The First I.M. Sechenov Moscow State Medical University, Moscow, Russia.

5: Department of Clinical and Community Sciences, University of Milan, and Department of Woman Child and Neonate, Fondazione IRCCS Cà Granda Ospedale Maggiore Policlinico,Milan, Italy.

6: Department of Medical and Surgical Sciences, Institute of Obstetrics and Gynecology, University of Foggia, Foggia, Italy

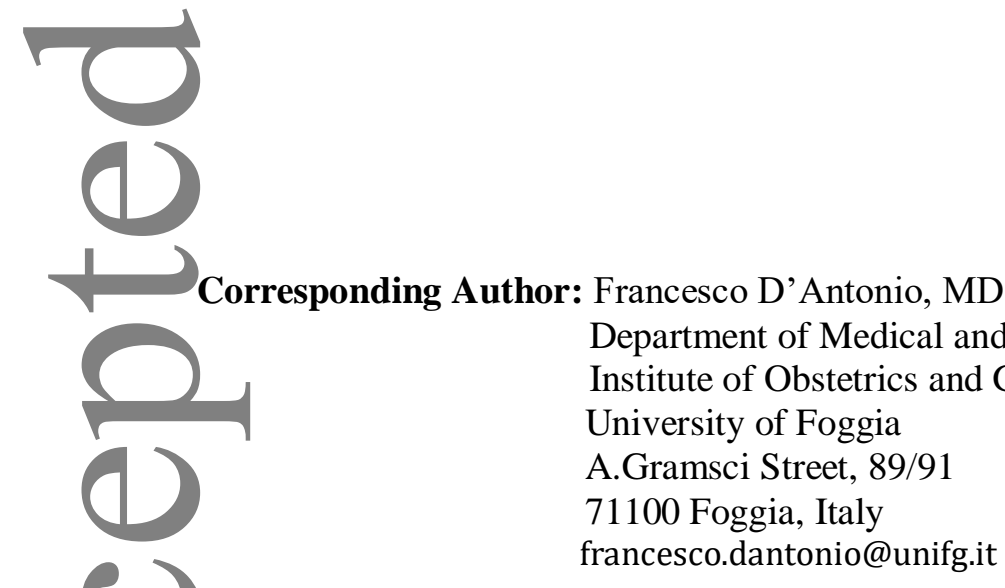

Conflict of interest statement: All the authors have no conflicts of interest to disclose

Funding : No funding was obtained for this study.

Data availability statement: research data are not shared

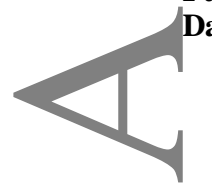

This article has been accepted for publication and undergone full peer review but has not been through the copyediting, typesetting, pagination and proofreading process which may lead to differences between this version and the Version of Record. Please cite this article as doi: $10.1002 /$ pd.5622 


\section{ABSTRACT}

Objectives: To perform a systematic review of studies reporting the outcome of fetuses with a prenatal diagnosis of isolated duplex collecting system (DCS).

Methods: Inclusion criteria were studies reporting the outcome of fetuses with a prenatal diagnosis of isolated DCS, defined as DCS not associated with other major structural anomalies at the time of diagnosis. The outcomes observed were: imaging features of DCS on prenatal ultrasound, associated anomalies detected exclusively at prenatal follow-up ultrasound and at birth, abnormal karyotype, symptoms at birth [including vesicoureteral reflux (VUR), urinary tract infections (UTI)], need for and type of surgical approach, complications after surgery and accuracy of prenatal ultrasound in correctly identifying this anomaly.

Results: Eleven studies (284 fetuses with a prenatal diagnosis of DCS) were included. On Jultrasound, DCS was associated with ureterocele in $70.7 \%$ and with megaureter in $36.6 \%$ of cases. Worsening of pelvic/ureteric dilatation was reported to occur in $41.3 \%$ of fetuses. At birth, $4.3 \%$ of fetuses affected by DCS showed associated renal anomalies. After birth, VUR and UTI presented in $51.3 \%$ and $21.7 \%$ of children respectively, while $33.6 \%$ required surgery. Prenatal diagnosis of DCS was confirmed in $90.9 \%$ of included cases.

Conclusion: DCS diagnosed prenatally is associated with a generally good outcome. Prenatal ultrasound has a good diagnostic accuracy, while detailed post-natal assessment is required in order to identify associated renal anomalies.

\section{INTRODUCTION}

Duplex collecting system (DCS) is one of the most common urinary tract anomalies reported in the pediatric literature, with an incidence ranging from $0.7-4 \%{ }^{1}$. DCS is characterized by the presence of two pyelocaliceal systems within the same renal unit due to an incomplete fusion of upper and lower pole moieties resulting in a variety of complete or incomplete duplications of the collecting system with single or double ureters ${ }^{1}$.

Prenatal diagnosis of DCS relies on the visualization of two non-communicating renal pelvises, pelvis dilatation or cystic areas in the upper or lower pole representing calyceal or ureteral dilatation and the presence of a cystic anechoic structure within the bladder suggesting a ureterocele ${ }^{2}$ (Figure 1).The actual detection rate of ultrasound in detecting DCS has not been consistently reported and the large majority of cases diagnosed before birth are those presenting with dilatation of one or both renal moieties, while those cases not presenting with dilatation may be easily overlooked at the 
scan. Differential diagnoses of DCS include hydronephrosis, polycystic kidneys, solitary renal cysts or pelvi-ureteric junction obstruction ${ }^{3}$.

The outcome of children affected by DCS has been reported to be generally good, although recurrent urinary infections, obstruction and reflux may lead to impaired renal function and need for surgery ${ }^{4-6}$.

Despite this, the natural history of DCS in utero has still to be completely elucidated yet. The small sample size of previously published series, their short period of follow-up, inclusion of cases affected by other anomalies do not allow to extrapolate the actual risk of adverse perinatal outcome in fetuses affected by this anomaly.

- The aim of this systematic review was to explore the outcome of isolated DCS diagnosed Jprenatally.

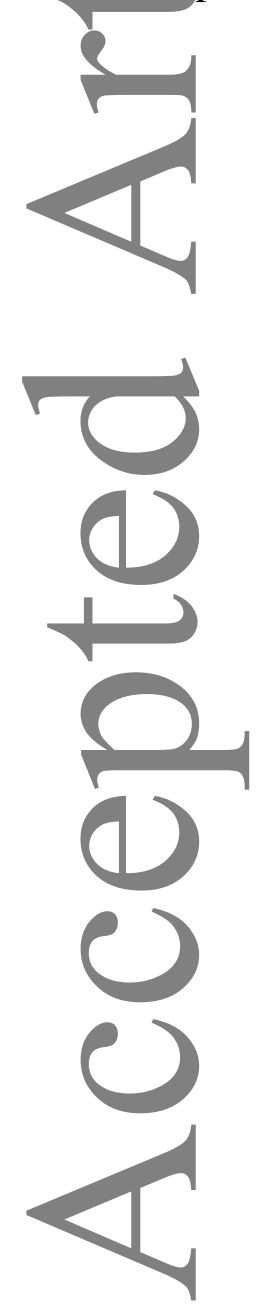




\section{METHODS}

\section{Protocol, eligibility criteria, information sources and search}

This review was performed according to an a-priori designed protocol and recommended for systematic reviews and meta-analysis ${ }^{7}$. Medline and Embase databases were searched electronically on the 10.01.2019 utilizing combinations of the relevant medical subject heading (MeSH) terms, key words, and word variants for "duplex collecting system", "kidneys", "ultrasound" and "outcome". The search and selection criteria were restricted to English language. Reference lists of relevant articles and reviews were hand searched for additional reports. Prisma guidelines were followed ${ }^{8}$.

The study was registered with the PROSPERO database (registration number: CRD42019125826).

\section{Inclusion criteria}

Inclusion criteria were studies reporting the outcome of fetuses with a prenatal diagnosis of isolated DCS, defined as DCS not associated with other major structural anomalies at the time of diagnosis. Only studies reporting a prenatal diagnosis of isolated DCS were considered suitable for the inclusion in the current systematic review; post-natal studies or studies from which cases diagnosed pre-natally could not be extracted were excluded. Paediatric and surgical series including only symptomatic cases or patients undergoing surgical treatment not reporting information on the observed outcomes were also excluded. Studies published before 2000 were also excluded, as we considered that advances in prenatal imaging techniques, improvements in the diagnosis and definition of this anomaly make these less relevant. Finally, studies not providing a clear clossification of the anomaly were not considered suitable for the inclusion in the current review.

Only full text articles were considered eligible for the inclusion; case reports, conference abstracts and case series with fewer than 3 cases of DCS, irrespective of the fact that the anomaly was isolated or not, were also excluded in order to avoid publication bias.

\section{Outcomes explored}

The outcomes explored were:

- Imaging features of DCS on prenatal ultrasound, including association with ureterocele and/or megaureter on prenatal ultrasound.

- Associated anomalies detected exclusively at prenatal follow-up ultrasound.

- Associated anomalies detected exclusively at birth and missed at prenatal ultrasound.

- Abnormal karyotype. 
- Symptoms at birth, including vesicoureteral reflux (VUR) and/or urinary tract infections (UTI).

- Need for surgery and type of surgical approach performed.

- Complications after surgical treatment including VUR and UTI.

- Detection rate of prenatal ultrasound in correctly identifying DCS.

Furthermore, we aimed to report the explored outcome in fetuses with DCS associated compared to those not associated with ureterocele.

Two authors (FB, DB) reviewed all abstracts independently. Agreement regarding potential relevance was reached by consensus; full text copies of those papers were obtained and the same two reviewers independently extracted relevant data regarding study characteristics and pregnancy outcome. Inconsistencies were discussed by the reviewers and consensus reached or by discussion with a third author. If more than one study was published for the same cohort with identical endpoints, the report containing the most comprehensive information on the population was included to avoid overlapping populations.

Quality assessment of the included studies was performed using the Newcastle-Ottawa Scale (NOS) for cohort studies; according to NOS, each study is judged on three broad perspectives: the selection of the study groups; the comparability of the groups; and the ascertainment outcome of interest $^{9}$. Assessment of the selection of a study includes the evaluation of the representativeness of the exposed cohort, selection of the non-exposed cohort, ascertainment of exposure and the demonstration that outcome of interest was not present at start of study. Assessment of the comparability of the study includes the evaluation of the comparability of cohorts on the basis of the design or analysis. Finally, the ascertainment of the outcome of interest includes the evaluation of the type of the assessment of the outcome of interest, length and adequacy of follow-up 9 . According to NOS a study can be awarded a maximum of one star for each numbered item within the Selection and Outcome categories. A maximum of two stars can be given for Comparability ${ }^{9}$.

\section{Statistical analysis}

We used meta-analyses of proportions to combine data. Funnel plots displaying the outcome rate from individual studies versus their precision (1/standard error) were carried out with an exploratory aim. Tests for funnel plot asymmetry were not used when the total number of publications included for each outcome was less than ten. In this case, the power of the tests is too low to distinguish chance from real asymmetry ${ }^{10-16}$. 
Between-study heterogeneity was explored using the $\mathrm{I}^{2}$ statistic, which represents the percentage of between-study variation that is due to heterogeneity rather than chance. A value of $0 \%$ indicates no observed heterogeneity, whereas $\mathrm{I}^{2}$ values of $\geq 50 \%$ indicate a substantial level of heterogeneity. All analyses were performed using Stata version 13.1 (Stata Corp., College Station, TX, 2013).

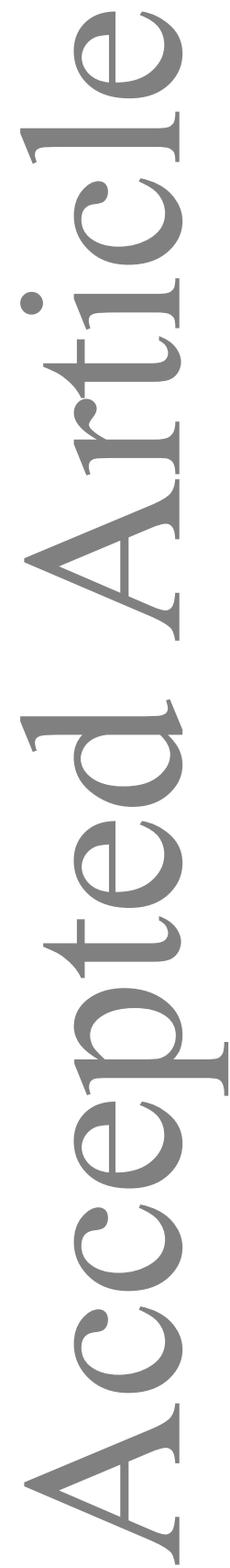




\section{RESULTS}

\section{Study selection and characteristics}

97 articles were identified, 71 were assessed with respect to their eligibility for inclusion (Supplementary Table 1) and 11 studies were included in the systematic review (Table 1, Figure $2)^{4,6,17-25}$. These 11 studies included 284 fetuses affected by isolated DCS on ultrasound, defined as the presence of DCS with no associated anomalies at the time of diagnosis.

The results of the quality assessment of the included studies using Newcastle-Ottawa Scale (NOS) are presented in Table 2. Most of the included studies showed an overall good score regarding the selection and comparability of the study groups, and for ascertainment of the outcome of interest. The main weaknesses of these studies were their retrospective design, small sample size, heterogeneity of outcomes observed, different protocols for antenatal management of fetuses affected by DSC and lack of stratification according to the laterality of the defect for the majority of the included studies.

\section{Synthesis of the results}

Eight studies, (145 fetuses) reported information on prenatal ultrasound features of fetuses affected by DCS. Ureterocele and megauretere were associated with DCS on ultrasound in $70.7 \%$ (95\% CI 44.9-90.8) and $36.6 \%$ (95\% CI 16.2-60.0) of cases respectively, while megaureter with no associated ureterocele was described in $10.2 \%$ (95\% CI 3.5-19.8) of fetuses with a prenatal diagnosis of DCS.

(2) exclusively at follow-up ultrasound scan; conversely, worsening of pelvic and/or ureteric dilatation was reported to occur in $41.3 \%$ (95\% CI 25.2-58.4) of fetuses with a prenatal diagnosis of DCS (Table 3). At birth, 4.3\% (95\% CI 0.4-12.1) of fetuses affected by DCS showed associated anomalies in either kidneys, while there were no major extra-renal anomalies detected exclusively at birth and missed at the scan in fetuses labelled as being affected by isolated DCS.

Information on the occurrence of abnormal karyotype was difficult because it was not possible to extrapolate the number of cases affected by isolated DCS undergoing invasive testing. However, none of the included studies reported the occurrence of a chromosomal anomaly in fetuses with a prenatal diagnosis of isolated DCS, although there was no mention on the type of genetic analysis undertaken. 
After birth, VUR and UTI presented in 51.3\% (95\% CI 28.4-74.0) and 21.7\% (95\% CI 11.3-34.5) of children with a prenatal diagnosis of DCS respectively. When stratifying the analysis according to the presence of ureterocele, 58.7\% (95\% CI 36.2-79.4) of cases with DCS and ureterocele had VUR while the corresponding figure for cases without ureterocele was 35.2\% (95\% CI 20.1-52.1). Likewise, the occurrence of UTI was $21.6 \%$ (95\% CI 8.8-38.1) in cases with and $32.9 \%$ (95\% CI 15.1-53.6) in those without ureterocele (Table 3).

Among the cases included in the present review, 33.6\% (95\% CI 4.0-58.4) had surgery and 39.7\% (95\% CI 19.4-62.2) required heminephrectomy. After surgery VUR affected 46.2\% (5.7-90.3) of children with a prenatal diagnosis of DCS, while UTI occurred in 6.0\% (95\% CI 0.5-28.8) of cases. Prenatal diagnosis of DCS was confirmed in $90.9 \%$ (95\% CI 77.4-99.3) of included cases, with the remaining cases found to be normal or affected by other renal anomalies at birth (Table 3).

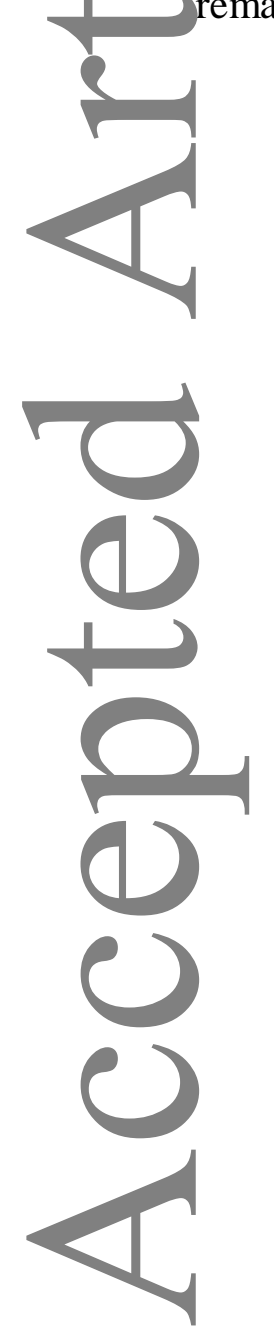




\section{DISCUSSION}

\section{Main findings}

The findings from this systematic review showed that DCS diagnosed prenatally was associated with a generally good outcome. The rate of associated anomalies diagnosed at follow-up or at birth was low, although about $4 \%$ of cases showed associated renal anomalies in either kidney. After birth, VUR and UTI presented in $51.3 \%$ and $21.7 \%$ of children with a prenatal diagnosis of DCS respectively, while $33.6 \%$ required surgery. Ultrasound has a good diagnostic accuracy in identifying DCS prenatally with about $90 \%$ of diagnoses confirmed at birth.

It was not possible to extrapolate a robust evidence on the actual association between DCS and chromosomal anomalies.

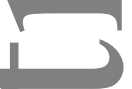

\section{Co}

Comparison with other systematic reviews, sstrengths and limitations

This is to our knowledge the first systematic review exploring the outcome of fetuses with a prenatal diagnosis of DCS. Thorough literature search and the multitude of outcomes explored represent the main strengths of the present systematic review. The small number of included studies, their retrospective non-randomized design, differences among the included populations in prenatal management and time at follow-up of fetuses with an ultrasound diagnosis of DCS represent the main limitations. The small number of included cases represents the major limitation of the present review and it did not allow to perform a comprehensive sub-group analysis according to the presence of renal pelvis dilatation. This is fundamental as the presence of renal pelvis dilatation is likely to affect some of the explored outcomes (i.e. VUR and UTI). Likewise, the mall number of cases included for each of the explored outcomes led to wide confidence intervals for most of the pooled proportion, thus affecting the robustness of the results. Differences in postnatal follow-up of children with a prenatal diagnosis of DCS represent another major limitation. Some anomalies may be evident only months after birth, thus affecting the rate of associated malformations detected prenatally. Furthermore, the detection rate of DCS reported in the present systematic review might have been biased by the fact that the included studies come from centers with high expertise in prenatal diagnosis of fetal anomalies. DCS remains a challenging diagnosis unless specific signs such as hydronephrosis are present and a considerable proportion of cases remains undiagnosed even for years after birth. In this scenario, the incidence of some of the explored outcomes might have been overestimated on the basis that mostly cases presenting with pelvic dilatation were included in this review. Finally, we could not quantify the incidence of the different explored outcomes in fetuses presenting compared to those not presenting with calyceal dilation on ultrasound. 
Despite these limitations, the present study represents the most comprehensive up-to-date metaanalysis of the outcome of fetuses with a prenatal diagnosis of isolated DCS.

\section{Implications for clinical practice}

Advances in prenatal imaging techniques have led to an increased detection rate of fetal anomalies in utero. DCS is generally considered a benign condition with a generally favourable outcome; despite this, the appropriate pre-natal management once DCS is diagnosed on ultrasound has still to be determined.

\section{(2)}

Prenatal diagnosis of DCS is challenging in the absence of hydronephrosis and this anomaly can be Jeasily undetected on antenatal ultrasound. The most common ultrasound presentation of DCS is the dilatation of one or two renal pelvis which may be associated with the presence of ureterocele or megaureter. In the present review, ureterocele and megauretere were associated with DCS on ultrasound in $70.7 \%$ and $36.6 \%$ of cases respectively. These findings suggest that once DCS is detected at the scan a detailed ultrasound assessment is warranted in order to identify the presence of an ureterocele which can potentially affect the short- and long-term outcomes of these children. Furthermore, serial follow-up scans are needed in pregnancy in order to promptly detect a worsening of calyceal or ureteral dilation, which can occur in $41.3 \%$ of cases affected by isolated DCS, while the risk of associated major anomalies detected exclusively after birth and missed at the scan appears very low and none of the cases included in the present review had additional extrarenal anomalies missed at ultrasound. However, $4.3 \%$ of fetuses had associated anomalies in the umpary system, thus highlighting the need for a detailed post-natal assessment in order to detect anomalies potentially affecting short- and long-term renal function.

Association with chromosomal anomalies represents another relevant issue. It was not possible to extrapolate data regarding the number of fetuses undergoing invasive test, although none of the included study reported the occurrence of a chromosomal anomaly when isolated DCS was detected on ultrasound. Furthermore, there was no mention on the role of chromosomal microarray in detecting associated submicroscopic anomalies in fetuses with isolated DCS and normal karyotype. In this scenario, further evidence is needed in order to elucidate whether an invasive test should be offered to parents.

Post-natal management of fetuses with DCS is also debated and depends upon the function of the upper moiety, clinical symptoms, presence and location of ureterocele. After birth, children with a 
prenatal diagnosis of DCS should undergo renal and bladder ultrasonography and voiding cystourethrography (VCUG), in order to confirm diagnosis, detected the presence of VUR, while nuclear renal scanning may be indicated in case of symptomatic cases in order to quantify renal function $^{26}$.

Asymptomatic neonates in the absence of severe hydroureteronephrosis are generally considered at low risk of developing urinary tract infections during the first months of life. In these children antibiotic prophylaxis and close follow-up may be a reasonable option in the first 3-6 months of life. Conversely, those presenting with severe VUR and recurrent UTI are at higher risk of surgical intervention ${ }^{26-23}$.

In the present review, the incidence of urinary tract infections after birth was $21.7 \%$, while VUR Joccurred in $51.3 \%$ of cases. More importantly, when stratifying the analysis according to the presence of ureterocele, $58.7 \%$ of cases with DCS and ureterocele had VUR while the corresponding figure for cases without ureterocele was 35.2\%. These findings suggest that cases affected by DCS showing signs of ureterocele at the scan may represent a sub-set of fetuses at higher risk of clinical symptoms and abnormal renal function, requiring a stricter follow-up after birth.

Although these figures may represent an overestimation of the actual occurrence of clinical symptoms in children with isolated DCS because the large majority of included cases presented with calyceal or ureteral dilatation on the scan, it highlights the need of a detailed post-natal assessment of children with a prenatal diagnosis of DCS, especially when signs of hydronephrosis or the presence of ureterocele are detected at the scan.

\section{CONCLUSION}

DCS diagnosed prenatally is associated with a generally good outcome. Prenatal ultrasound has a good diagnostic accuracy in detecting this anomaly, while detailed post-natal assessment is required

in order to identify associated renal anomalies, especially when hydronephrosis or ureterocele are detected at the scan. Finally, further evidence is needed on whether invasive prenatal diagnosis should be offered to parents in case of isolated anomaly. 


\section{REFERENCES}

1. Didier RA, Chow JS, Kwatra NS, Retik AB et al. The duplicated collecting system of the urinary tract: embryology, imaging appearances and clinical considerations. Pediatric Radiology 2017;47:1526-1538.

2. Abuhamad AZ, Horton CE, Horton SH, Evans AT. Renal duplication anomalies in the fetus: clues for prenatal diagnosis. Ultrasound Obstet Gynecol 1996;7:174-177.

3. Vergani P, Ceruti P, Locatelli A et al. Accuracy of prenatal ultrasonographic diagnosis of duplex renal system. J Ultrasound Med 1999;18:463-467.

4. Direnna T, Leonard MP. Watchful waiting for prenatally detected ureteroceles. J Urol. 2006;175:1493-1495.

5. Gundeti MS, Ransley PG, Duffy PG et al. Renal outcome following heminephrectomy for duplex kidney. J Urol. 2005;173:1743-1744.

6. Plevani C, Locatelli A, Paterlini G et al. Fetal hydronephrosis: natural history and risk factors for postnatal surgery. J Perinat Med. 2014;42:385-391.

7. Higgins JPT, Green, S.Cochrane Handbook for Systematic Reviews of Interventions. The Cochrane Collaboration; 2011. Available from: www.cochrane-handbook.org.

C 8. Moher D, Liberati A, Tetzlaff J, Altman DG; PRISMA Group. Preferred reporting items for Systematic reviews and meta-analyses: the PRISMA statement. PLoS Med. 2009 21;6:e1000097.

9. Ottawa Hospital research institute. Newcastle-Ottawa Scale for assessing the quality of non rarldomised in meta-analyses.

http://www.ohri.ca/programs/clinical_epidemiology/oxford.asp

[Accessed 1 March 2015]

10. Hunter JP, Saratzis A, Sutton AJ, et al. In meta-analyses of proportion studies, funnel plots C were found to be an inaccurate method of assessing publication bias. $\mathrm{J}$ Clin Epidemiol 2014;67:897-903.

11. Friedrich JO, Adhikari NK, Beyene J. Inclusion of zero total event trials in meta-analyses maintains analytic consistency and incorporates all available data. BMC Med Res Methodol. 2007;7:5.

12. Sweeting MJ, Sutton AJ, Lambert PC. What to add to nothing? Use and avoidance of continuity corrections in meta-analysis of sparse data. Stat Med. 2004;23:1351-1375.

13. Bradburn MJ, Deeks JJ, Berlin JA, Russell Localio A. Much ado about nothing: a comparison of the performance of meta-analytical methods with rare events. Stat Med. 2007;26:5377. 
14. Newcombe RG. Two-sided confidence intervals for the single proportion: comparison of seven methods. Stat Med 1998:17;857-72.

15. Manzoli L, De Vito C, Salanti G et al. Meta-analysis of the immunogenicity and tolerability of pandemic influenza A 2009 (H1N1) vaccines. PloS One. 2011;6: e24384.

16. Egger M, Smith GD, Schneider M, Minder CE. Bias in meta-analysis detected by a simple, graphical test. BMJ 1997;315:629-634

17. Visuri S, Jahnukainen T, Taskinen S. Prenatal complicated duplex collecting system and ureterocele-important riskfactors for urinary tract infection. J Pediatr Surg. 2018;53:813-817.

18. Adiego B, Martinez-Ten P, Perez-Pedregosa J et al. Antenatally diagnosed renal duplex anomalies: sonographic features and long-term postnatal outcome. J Ultrasound Med. 2011;30:809815 .

19. Chertin B, Rabinowitz R, Pollack A et al. Does prenataldiagnosis influence the morbidity associated with left in situnonfunctioning or poorly functioning renal moiety after endoscopic punctureof ureterocele?. J Urol. 2005 ;173:1349-1352.

20. Coplen DE, Austin PF. Outcome analysis of prenatally detected ureteroceles associated with multicystic dysplasia. Urol. 2004;172:1637-1639.

21. Whitten SM, McHoney M, Wilcox DT et al. Accuracy of antenatal fetal ultrasound in the diagnosis of duplex kidneys. Ultrasound Obstet Gynecol. 2003;21:342-346.

22. Bolduc S, Upadhyay J, Sherman C et al. Histology of upper pole is unaffected by prenatal diagnosis in duplex systemureteroceles. J Urol. 2002;168:1123-1126.

23. Upadhyay $\mathrm{J}$, Bolduc S, Braga L et al. Impact of prenatal diagnosis on the morbidity associated with ureterocelemanagement. J Urol. 2002;167:2560-2565.

24. Shankar KR, Vishwanath N, Rickwood AM. Outcome of patients with prenatally detected duplex system ureterocele; natural history of those managed expectantly. J Urol. 2001;165:12261228.

25. Besson R, Ngoc BT, Laboure S, Debeugny P. Incidence of urinary tract infection in neonates with antenatally diagnosed ureteroceles. Eur J Pediatr Surg. 2000;10:111-113.

26. Stein R, Dogan HS, Hoebeke P, Kočvara R, Nijman RJ, Radmayr C, Tekgül S; European Association of Urology; European Society for Pediatric Urology. Urinary tract infections in children: EAU/ESPU guidelines. Eur Urol. 2015;67:546-58.

27. Herz D, Merguerian P, McQuiston L. Continuous antibiotic prophylaxis reduces the risk of febrile UTI in children with asymptomatic antenatal hydronephrosis with either ureteral dilation, high-grade vesicoureteral reflux, or ureterovesical junction obstruction. J Pediatr Urol. 2014;10:650-654. 
28. Castagnetti M, Vidal E, Burei M et al. Duplex system ureterocele in infants: should we reconsider the indications for secondary surgery after endoscopic puncture or partial nephrectomy?. J Pediatr Urol. 2013;9:11-16.

29. Avlan D, Gündoğdu G, Delibaş A, Nayci A. Pyeloureterostomy in the management of the lower pole pelvi-ureteric junction obstruction in incomplete duplicated systems. Urology 2010;76:1468-1471.

30. Kavanagh A, McAuley I, Longpre M, Macneily AE. Atrophic upper pole of a duplex collecting system masquerading as suprarenal mass: a case study and literature review. Can Urol Assoc J. 2010;4:E94-96.

31. Braga LH, Moriya K, El-Hout Y, Farhat WA. Ureteral duplication with lower poleureteropelvic junction obstruction: laparoscopic pyeloureterostomy as alternativeto open approach in children. Urology. 2009;73:374-376.

32. VanderBrink BA, Cain MP, Gilley D et al. Reconstructive surgery for lower pole ureteropelvic junction obstruction associated with incomplete ureteral duplication. J Pediatr Urol. 2009;5:374-377.

33. Afshar K, Papanikolaou F, Malek R, et al.Vesicoureteral reflux and complete ureteral duplication. Conservative or surgical management? J Urol. 2005;173:1725-7.

Table 1. General characteristics of the studies included in the systematic review.

\begin{tabular}{|c|c|c|c|c|c|c|c|c|c|}
\hline Author & $\begin{array}{l}\text { Ye } \\
\text { ar }\end{array}$ & Country & $\begin{array}{l}\text { Study } \\
\text { design }\end{array}$ & $\begin{array}{l}\text { Study } \\
\text { period }\end{array}$ & $\begin{array}{c}\text { Prenatal } \\
\text { imaging }\end{array}$ & $\begin{array}{c}\text { GA at } \\
\text { diagnosis (w) }\end{array}$ & $\begin{array}{c}\text { Outco } \\
\text { mes } \\
\text { observ } \\
\text { ed }\end{array}$ & $\begin{array}{l}\text { Time at post-natal } \\
\text { follow-up }\end{array}$ & $\begin{array}{c}\text { Cases } \\
\text { (n) }\end{array}$ \\
\hline Visuri & $\begin{array}{l}20 \\
1 / 1\end{array}$ & Finland & $\begin{array}{l}\text { Retrospec } \\
\text { tive }\end{array}$ & $\begin{array}{l}2003- \\
2013\end{array}$ & US & NS & $\begin{array}{l}\text { prenata } \\
1 \text { US } \\
\text { feature } \\
\text { s, } \\
\text { sympto } \\
\text { ms, } \\
\text { need } \\
\text { for } \\
\text { surgery }\end{array}$ & $5.5(1.7-12.2) \mathrm{y}$ & 34 \\
\hline Ple & $\begin{array}{l}20 \\
14\end{array}$ & Italy & $\begin{array}{l}\text { Retrospec } \\
\text { tive }\end{array}$ & $\begin{array}{l}2002- \\
2007\end{array}$ & US & $27,2+-6.4 \mathrm{w}$ & $\begin{array}{l}\text { prenata } \\
1 \text { US } \\
\text { feature } \\
\text { s, need } \\
\text { for } \\
\text { surgery }\end{array}$ & $6 \mathrm{~m}$ & 5 \\
\hline$\underset{8}{\operatorname{Adieg} \mathrm{I}^{\mathrm{T}}}$ & $\begin{array}{l}20 \\
10\end{array}$ & Spain & $\begin{array}{l}\text { Retrospec } \\
\text { tive }\end{array}$ & $\begin{array}{c}2003200 \\
9\end{array}$ & US & $\begin{array}{c}27.9 \pm 6.5 \\
(19-34)\end{array}$ & $\begin{array}{l}\text { prenata } \\
1 \text { US } \\
\text { feature } \\
\text { s, } \\
\text { additio } \\
\text { nal } \\
\text { anomal } \\
\text { ies } \\
\text { detecte }\end{array}$ & $37 \mathrm{~m}(10-72 \mathrm{~m})$ & 21 \\
\hline
\end{tabular}




\begin{tabular}{|c|c|c|c|c|c|c|c|c|c|}
\hline & & & & & & & $\begin{array}{c}\mathrm{d} \text { post } \\
\text { natally, } \\
\text { sympto } \\
\mathrm{ms}, \\
\text { need } \\
\text { for } \\
\text { surgery }\end{array}$ & & \\
\hline$\underset{4}{\text { Direnna }}$ & $\begin{array}{l}20 \\
06\end{array}$ & Canada & $\begin{array}{l}\text { Retrospec } \\
\text { tive }\end{array}$ & $\begin{array}{l}1990- \\
2001\end{array}$ & US & NS & $\begin{array}{l}\text { prenata } \\
1 \text { US } \\
\text { feature } \\
\mathrm{s} \text {, need } \\
\text { for } \\
\text { surgery }\end{array}$ & $5 y(1-11 y)$ & 6 \\
\hline Che & $\begin{array}{l}20 \\
05\end{array}$ & Israel & $\begin{array}{c}\text { Retrospec } \\
\text { tive }\end{array}$ & $\begin{array}{l}1989- \\
2003\end{array}$ & US & NS & $\begin{array}{c}\text { prenata } \\
1 \text { US } \\
\text { feature } \\
\text { s, } \\
\text { sympto } \\
\text { ms, } \\
\text { need of } \\
\text { surgery } \\
\text {, need } \\
\text { of a } \\
\text { second } \\
\text { surgery }\end{array}$ & $9 y(1-14 y)$ & 35 \\
\hline $\mathrm{Cop}_{0}$ & $\begin{array}{l}20 \\
04\end{array}$ & Missouri & $\begin{array}{c}\text { Retrospec } \\
\text { tive }\end{array}$ & $\begin{array}{l}1998- \\
2002\end{array}$ & US & NS & $\begin{array}{c}\text { prenata } \\
1 \text { US } \\
\text { feature } \\
\text { s, } \\
\text { sympto } \\
\text { ms, } \\
\text { need } \\
\text { for } \\
\text { surgery }\end{array}$ & $36 \mathrm{~m}(14-54)$ & 4 \\
\hline & $\begin{array}{l}20 \\
03\end{array}$ & $\begin{array}{l}\text { United } \\
\text { Kingdom }\end{array}$ & $\begin{array}{l}\text { Retrospec } \\
\text { tive }\end{array}$ & $\begin{array}{l}1992- \\
2001\end{array}$ & US & NS & $\begin{array}{c}\text { prenata } \\
1 \text { US } \\
\text { feature } \\
\text { s, } \\
\text { additio } \\
\text { nal } \\
\text { anomal } \\
\text { ies } \\
\text { detecte } \\
\text { d post } \\
\text { natally, } \\
\text { diagno } \\
\text { stic } \\
\text { accurac } \\
\text { y } \\
\end{array}$ & $6 w-3 m$ & 47 \\
\hline & $\begin{array}{l}20 \\
02\end{array}$ & Canada & $\begin{array}{c}\text { Retrospec } \\
\text { tive }\end{array}$ & $\begin{array}{l}1992- \\
2000\end{array}$ & US & NS & $\begin{array}{c}\text { prenata } \\
1 \text { US } \\
\text { feature } \\
\text { s, } \\
\text { sympto } \\
\text { ms, } \\
\text { need } \\
\text { for } \\
\text { surgery }\end{array}$ & $20 \mathrm{~m}(1-180 \mathrm{~m})$ & 25 \\
\hline $\begin{array}{l}\text { Upadhy } \\
\text { ay }^{23}\end{array}$ & $\begin{array}{l}20 \\
02\end{array}$ & Canada & $\begin{array}{l}\text { Retrospec } \\
\text { tive }\end{array}$ & $\begin{array}{l}1992- \\
2000\end{array}$ & US & NS & $\begin{array}{c}\text { prenata } \\
1 \text { US } \\
\text { feature }\end{array}$ & $3,7 y$ & 40 \\
\hline
\end{tabular}

This article is protected by copyright. All rights reserved. 


\begin{tabular}{|c|c|c|c|c|c|c|c|c|c|}
\hline & & & & & & & $\begin{array}{c}\text { s, need } \\
\text { for } \\
\text { surgery } \\
, \\
\text { sympto } \\
\text { ms }\end{array}$ & & \\
\hline Shankar & $\begin{array}{l}20 \\
01\end{array}$ & $\begin{array}{c}\text { United } \\
\text { Kingdom }\end{array}$ & $\begin{array}{l}\text { Retrospec } \\
\text { tive }\end{array}$ & $\begin{array}{l}1984- \\
1999\end{array}$ & US & NS & $\begin{array}{l}\text { prenata } \\
1 \text { US } \\
\text { feature } \\
\text { s, } \\
\text { additio } \\
\text { nal } \\
\text { anomal } \\
\text { ies } \\
\text { detecte } \\
\text { d post } \\
\text { natally, } \\
\text { need } \\
\text { for } \\
\text { surgery } \\
\text {, } \\
\text { sympto } \\
\text { ms }\end{array}$ & $8 y(1-16.2)$ & 52 \\
\hline & $\begin{array}{l}20 \\
00\end{array}$ & France & $\begin{array}{l}\text { Retrospec } \\
\text { tive }\end{array}$ & $\begin{array}{l}1991- \\
1996\end{array}$ & US & NS & $\begin{array}{l}\text { prenata } \\
1 \text { US } \\
\text { feature } \\
\text { s, } \\
\text { sympto } \\
\text { ms, } \\
\text { need } \\
\text { for } \\
\text { surgery }\end{array}$ & $4 w$ & 15 \\
\hline
\end{tabular}

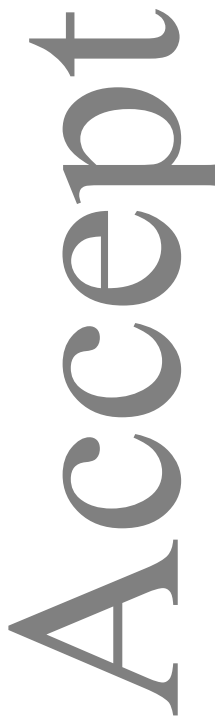

This article is protected by copyright. All rights reserved. 
Table 2. Quality assessment of the included studies according to Newcastle-Ottawa Scale (NOS) for cohort studies; a study can be awarded a maximum of one star for each numbered item within the Selection and Outcome categories (for a maximum of three stars). A maximum of two stars can be given for Comparability.

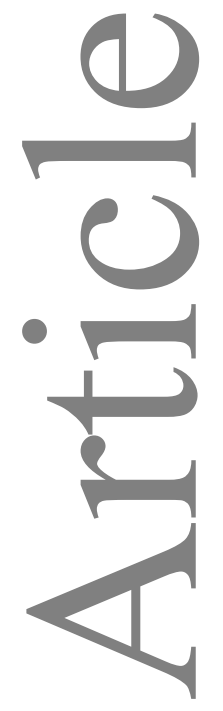

\begin{tabular}{|c|c|c|c|c|}
\hline Author & Year & Selection & Comparability & Outcome \\
\hline Visuri $^{17}$ & 2017 & $\star \star$ & $\star$ & $\star \star$ \\
\hline Plevani $^{6}$ & 2014 & $\star \star$ & $\star$ & $\star \star$ \\
\hline Adiego $^{18}$ & 2010 & $\star \star$ & $\star \star$ & $\star \star \star$ \\
\hline Direnna $^{4}$ & 2006 & $\star \star$ & $\star$ & $\star \star$ \\
\hline Chertin $^{19}$ & 2005 & $\star \star$ & $\star$ & $\star \star$ \\
\hline Coplen $^{20}$ & 2004 & $\star \star$ & $\star$ & $\star \star$ \\
\hline Whitten $^{21}$ & 2003 & $\star \star$ & $\star \star$ & $\star \star \star$ \\
\hline Bolduc $^{22}$ & 2002 & $\star \star$ & $\star$ & $\star \star$ \\
\hline Upadhyay $^{23}$ & 2002 & $\star \star$ & $\star$ & $\star \star$ \\
\hline Shankar $^{24}$ & 2001 & $\star \star$ & $\star$ & $\star \star$ \\
\hline Besson $^{25}$ & 2000 & $\star \star$ & $\star$ & $\star$ \\
\hline
\end{tabular}

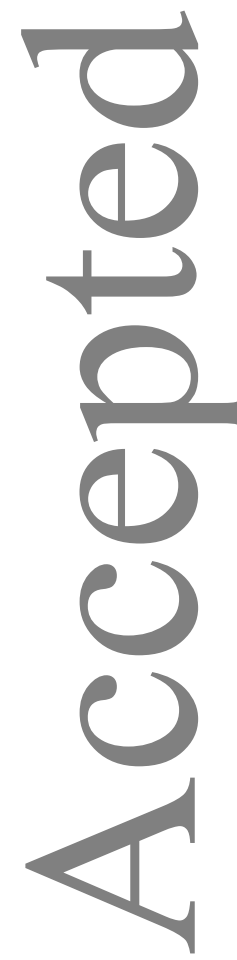


Table 3: Pooled proportion for the outcomes explored in this systematic review in fetuses with a prenatal diagnosis of DCS.

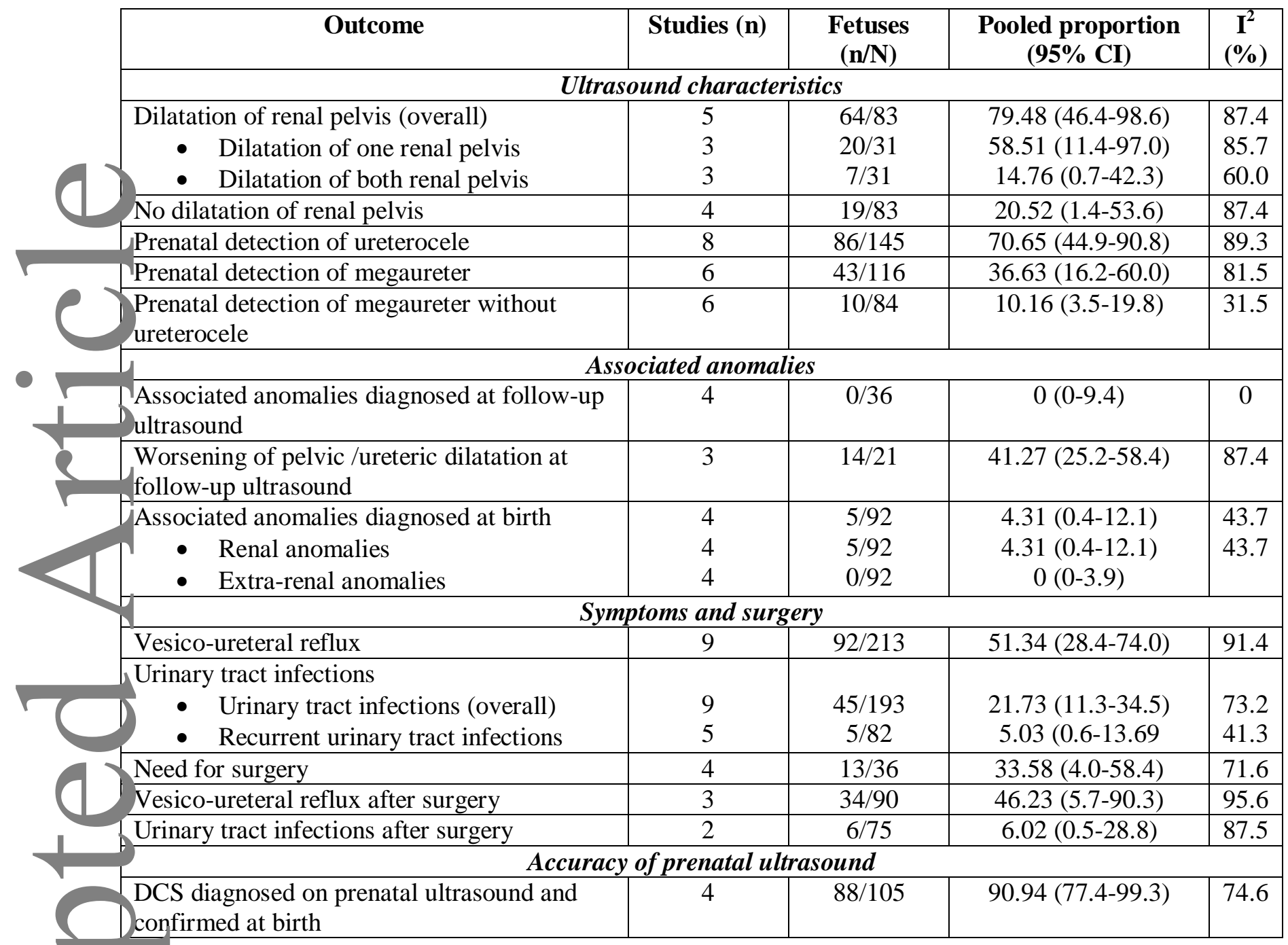

Supplementary Table 1. Excluded studies and reason for the exclusion.

\begin{tabular}{|c|c|c|c|}
\hline Author & Year & Title & Reason for the exclusion \\
\hline Ekmekci $^{12}$ & 2016 & $\begin{array}{c}\text { Prenatal Diagnosis of Bilateral Fetal Duplex } \\
\text { Kidneys and a Short Review about Duplex Kidneys }\end{array}$ & Case report \\
\hline Herz $^{13}$ & 2014 & $\begin{array}{c}\text { Continuous antibiotic prophylaxis reduces the risk } \\
\text { of febrile UTI in children with asymptomatic } \\
\text { antenatal hydronephrosis with either ureteral } \\
\text { dilation, high-grade vesicoureteral reflux, or }\end{array}$ & No cases of DCS \\
\hline
\end{tabular}




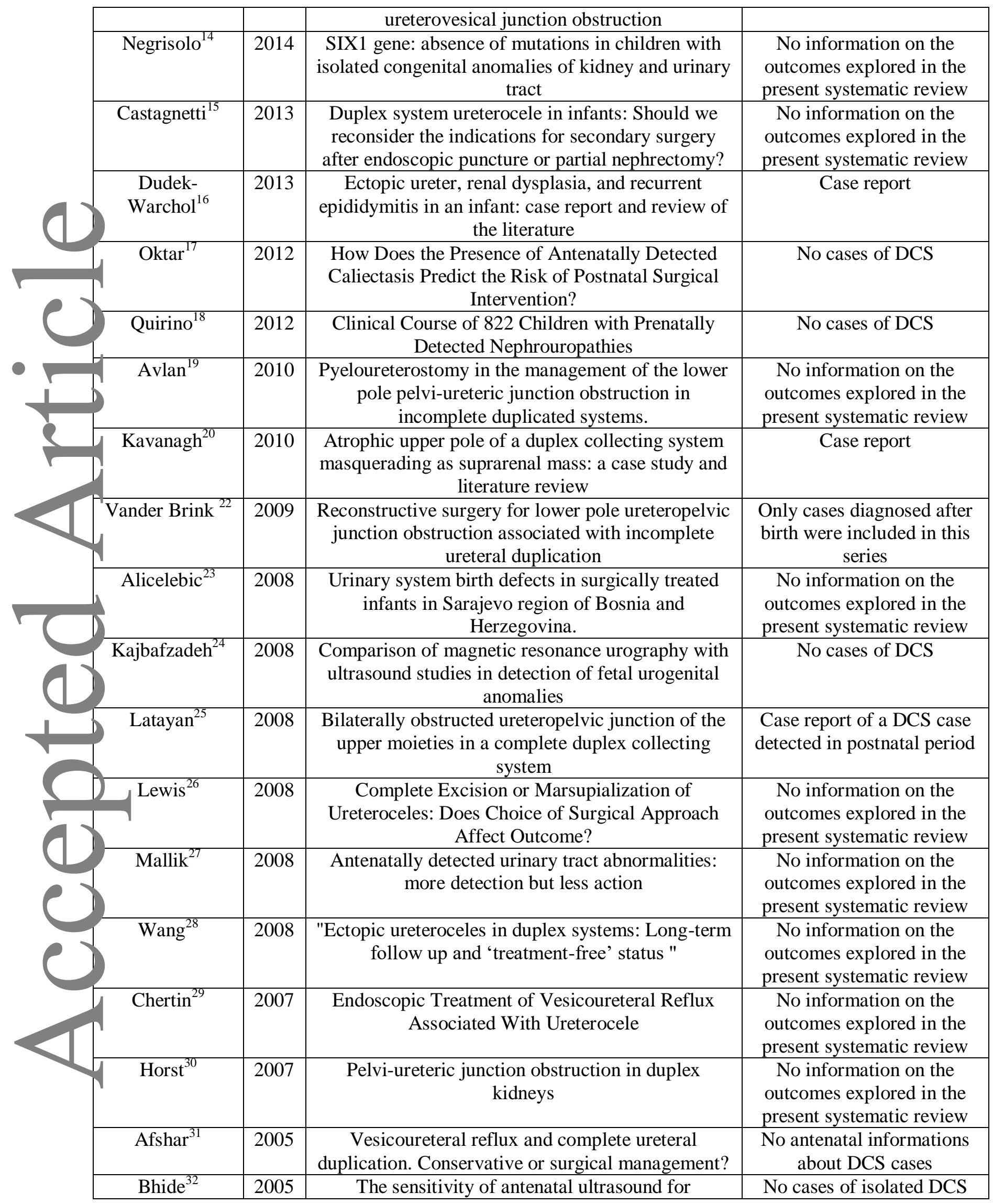




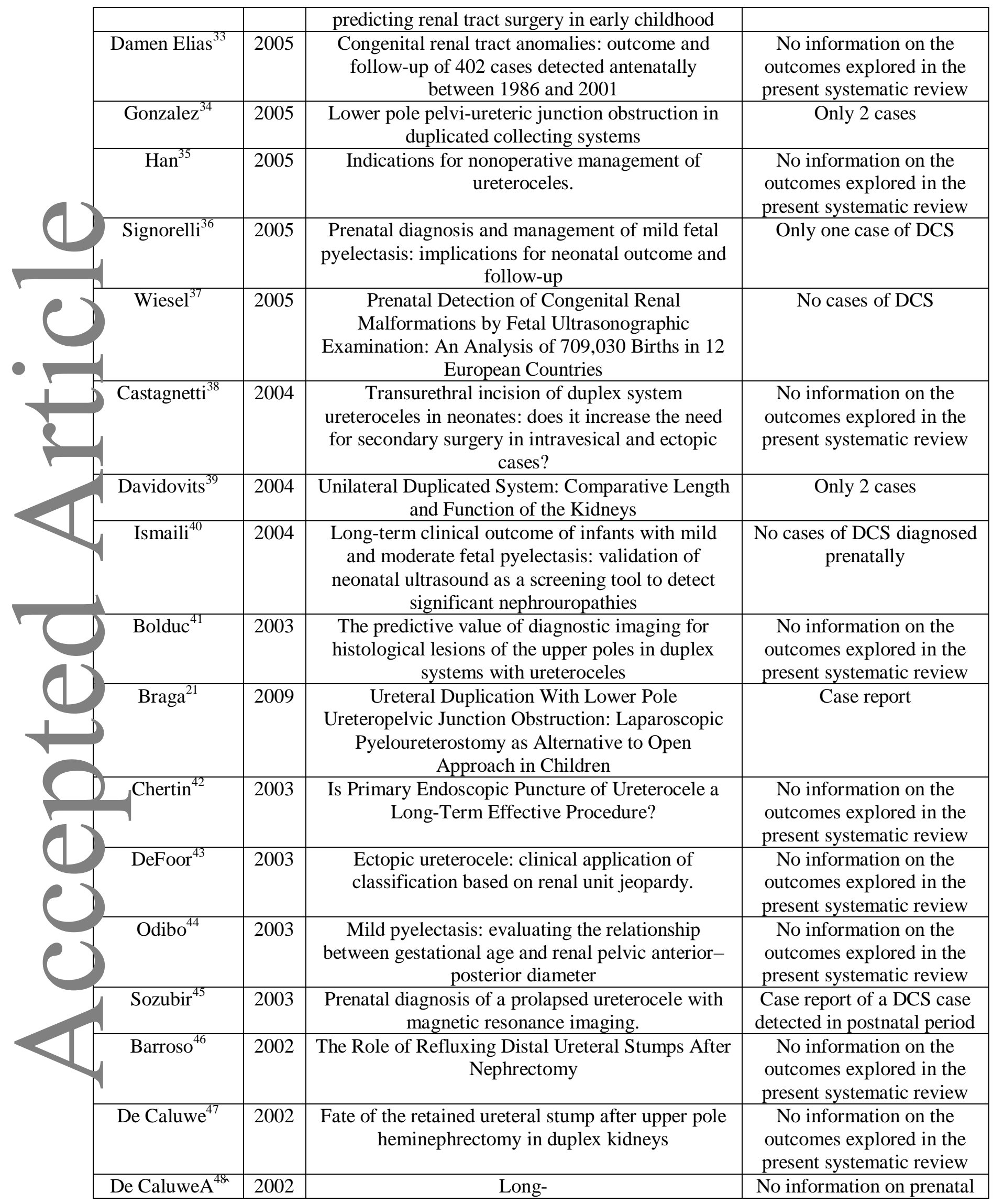




\begin{tabular}{|c|c|c|c|}
\hline & & $\begin{array}{l}\text { TermOutcomeoftheRetainedUreteralStumpafter } \\
\text { Lower Pole Heminephrectomy in Duplex Kidneys }\end{array}$ & features of DCS \\
\hline Ade-Ajayi ${ }^{49}$ & 2001 & $\begin{array}{l}\text { Upper pole heminephrectomy: is complete } \\
\text { ureterectomy necessary? }\end{array}$ & $\begin{array}{l}\text { No information on prenatal } \\
\text { features of DCS }\end{array}$ \\
\hline Androulakakis $^{50}$ & 2001 & $\begin{array}{c}\text { Outcome of the distal ureteric stump after } \\
\text { (hemi)nephrectomy and subtotal ureterectomy for } \\
\text { re ux or obstruction }\end{array}$ & $\begin{array}{l}\text { No information on prenatal } \\
\text { features of DCS }\end{array}$ \\
\hline Chen $^{51}$ & 2001 & $\begin{array}{l}\text { Prenatal diagnosis of de novo distal 11q deletion } \\
\text { associated with sonographic findings of unilateral } \\
\text { duplex renal system, pyelectasis and orofacial clefts }\end{array}$ & Case report \\
\hline Chertin $^{52}$ & 2001 & $\begin{array}{l}\text { Endoscopic Puncture of Ureterocele as a Minimally } \\
\text { Invasive and Effective Long-Term Procedure in } \\
\text { Children }\end{array}$ & $\begin{array}{l}\text { No information on prenatal } \\
\text { features of DCS }\end{array}$ \\
\hline Feldman $^{53}$ & 2001 & Evaluation and Follow-up of Fetal Hydronephrosis & $\begin{array}{l}\text { Only } 2 \text { cases of DCS } \\
\text { diagnosed postnatally }\end{array}$ \\
\hline Haliloglu $^{54}$ & 2001 & $\begin{array}{c}\text { Lower-pole ureteropelvic junction obstruction with } \\
\text { abnormal rotation in duplicated system }\end{array}$ & Case report \\
\hline $\mathrm{Ko}^{55}$ & 2001 & $\begin{array}{c}\text { Duplicated collecting system with lower pole } \\
\text { ureteropelvic junction obstruction }\end{array}$ & $\begin{array}{l}\text { Only } 2 \text { cases of DCS } \\
\text { diagnosed postnatally }\end{array}$ \\
\hline Aviram ${ }^{56}$ & 2000 & $\begin{array}{l}\text { The increase of renal pelvis dilatation in the fetus } \\
\text { and its significance }\end{array}$ & Only 2 cases of DCS \\
\hline Bruno $^{57}$ & 2000 & $\begin{array}{l}\text { Successful management of lower-pole moiety } \\
\text { ureteropelvic junction obstruction in a partially } \\
\text { duplicated collecting system using minimally } \\
\text { invasive retrograde endoscopic techniques. }\end{array}$ & Case report \\
\hline Cooper $^{58}$ & 2000 & $\begin{array}{l}\text { Long-term followup of endoscopic incision of } \\
\text { ureteroceles: intravesical versus extravesical. }\end{array}$ & $\begin{array}{l}\text { No information on prenatal } \\
\text { features of DCS }\end{array}$ \\
\hline de Jong ${ }^{59}$ & 2000 & $\begin{array}{l}\text { Ectopic ureterocele: results of open surgical therapy } \\
\text { in } 40 \text { patients. }\end{array}$ & No cases of DCS \\
\hline Hagg $^{60}$ & 2000 & The modern endoscopic approach to ureterocele. & $\begin{array}{l}\text { No information on prenatal } \\
\text { features of DCS }\end{array}$ \\
\hline Jednak $^{61}$ & 2000 & $\begin{array}{l}\text { A simplified technique of upper pole } \\
\text { heminephrectomy for duplex kidney. }\end{array}$ & $\begin{array}{c}\text { No information on prenatal } \\
\text { features of DCS }\end{array}$ \\
\hline
\end{tabular}



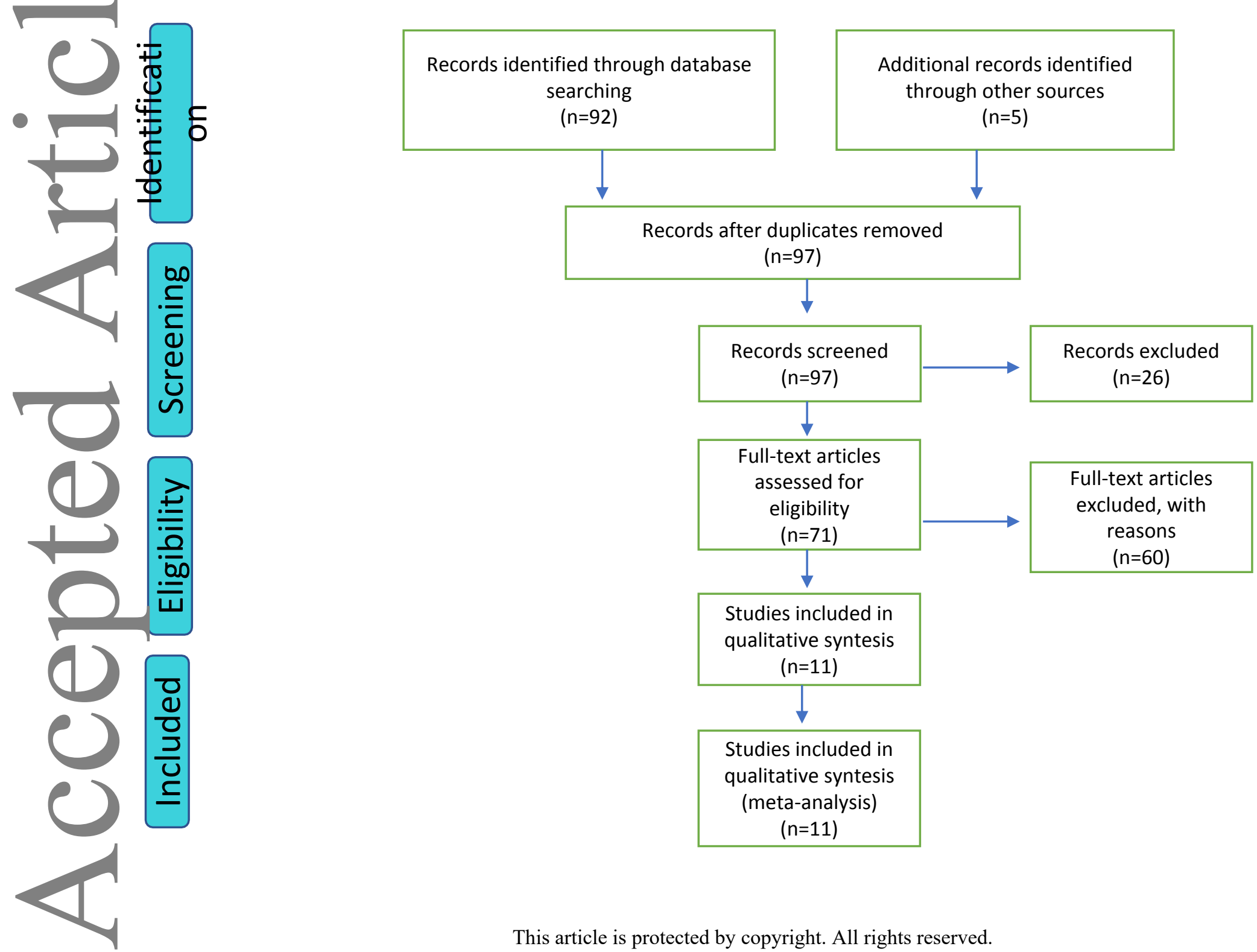

This article is protected by copyright. All rights reserved. 